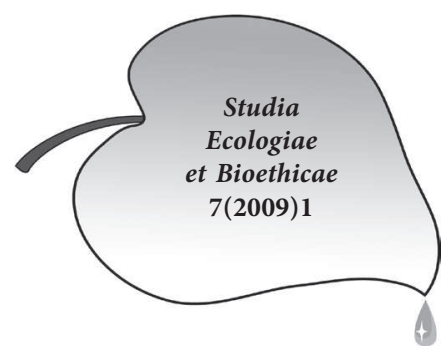

\title{
Ecology of women as a harmony of interior world and nature
}

\section{Introduction}

Jesus words from Gospel of Matthew (Mt 12, 25) “......" were the inspiration for consideration about harmony between internal environment and nature that is human ecology, and in these case women.

In order to obtain an image of harmony it is necessary to show at least the most vital elements forming both the internal harmony in a man, as well as its harmonious relations with the surroundings. In the discussion I would like to work with the subject of women ecology meaning what is characteristic and particular in her environment for her and what distinguishes her from man and his influence on his surroundings.

An important matter of harmony will be its elements, which create a whole. Harmony between needs, values and norms will be discussed further as a background for consideration about accepting femininity as a condition necessary to maintain balance in all aspects of human life.

In order for woman to truly accept her femininity and resulting from it specific way of women acting she must learn how to maintain balance at all levels of relations between internal and external environment.

Achievement of such a state as a permanent order of body and soul is only possible when woman knows what and how to protect. To achieve a state of conscience needed to realize femininity she has to be appropriately prepared through upbringing, forming and examples which will help a girl, teenager and then young woman in seeking truth about herself.

These questions come into mind:

- Whether in modern culture women at least intuitively protect themselves against invasive methods interfering with their natural biological cycle?

- Whether women know their bodies from biological and psychic side and whether they feel responsible for themselves? 
- Whether women connect their biological nature with specific psychic nature (emotions and moods)?

- Whether young women connect taking care of their biological fertility rhythm with sustaining internal femininity and harmony?

- If when expressing their outlook on life through membership of a religious faith and consider themselves religious it is applied in everyday life?

- Are they prepared to overcome the difficulties and accept their femininity?

- To what degree modern women are prepared to subordinate requirements of civilisation which are against nature in order to please others?

That is the reason why I started this research which is at initial stage of realisation

\section{Ecology of Woman}

Widely understood and practiced human ecology concerns relation between man and environment as a whole. It needs to be considered whether we can consider separately ecology of women and men. In Christian anthropology woman and man function in one humanity in terms of dignity, but as a woman and man in terms of constitution. Two different factors contribute to human fullness fulfilled in sexuality. Sex differentiates man in biological, psychic, social and as a consequence cultural aspects. That is why it can be justified to consider woman personality and nature in their own environment, as ecology of woman.

I let myself to use the term ecology of woman because I think that ecology (Greek oikos - home) as a study of home the nearest environment accurately shows the sense of environment, aura that woman creates around herself.

When we talk about ecology about environment it is closely associated with nature. In case of woman we can apply to the world of nature. Quoting poets from all ages starting with known to us "Song above songs" we can follow how poets connected with body and soul of a woman the whole "transfigured nature, which in body became personal beauty, gift of marriage and basic nourishment" (body of woman connected with her soul is flexibility of reed grass and liana and honeysuckle and palm it is foliage of forests, great grasses of prairie, fields of cereal... warmth of a haystack and gentleness of hills, and arched of bays... bunches and fruit, lakes and pigeons, snow and wheat, downpour and gazelle and fawn, sheep and lamb, and sometimes snake... Woman is "a secret spring", sea of the inside of a vine grape"; she is water and goblet; wave and shell, grotto and "closed garden"; heat, flame and "burning bush"; is all the flowers, and especially rose; is a thorn and scent, that what is given, exquisite, and what passes, the same and different; its orchard apple and pomegranate, and wild strawberry; is a berry of a vine grape, a bunch and vineyard, which gardener cuts so it can give more fruit.... She is water and wine; milk and honey; She is bread! Is nest and 
valley, lullaby, and arc, and home, and fortified city surrounded by towers! She is earth; seeds and roots are in her.... She is the moon, She - star... She dawn... She rainbow... She is "body", in which "word became body"!) [Echivard 1989, 43].

This piece full of poetry and fantasy demonstrates specificity of woman nature and her environment. An influence of woman characteristics and behaviours describes her in fundamental and distinct way from man behaviour. This is why in a developing human ecology I allow myself to find separate places for woman and man ecology.

\subsection{Rhythm of woman body as a main part of personality}

Comparing biological functioning of both sexes you can say that man's body is closed, it does not have a rhythm or mystery. Woman's body has natural rhythm, her fertility is cyclic. Biological rhythm does not depend on man's body, the dependence is opposite, it is woman's biological rhythm with its influence on psychology and spirituality and therefore personality of a woman is an indication for the body and sexuality of the man.

According to Echivard [Echivard 1989: 43] biology and spirituality are inseparable and that is why what is biological is a visible sign of is spiritual. Woman as the one who is the mystery of soul encrypted in the mystery of the body is always a muse.

Echivard writes, that woman is a mediator of beauty, mediator between God and man, between man and nature, is a mediator of love. Woman's body is a mediator between spouse and child.

He also mentions that the biological rhythm of fertility with its psychic an spiritual conditioning is wisdom and a guide for body and sexuality of man, it teaches the man unconditional love, sacrifice and temperance. Acquired and realized biological rhythm of fertility protects against half-measure solutions of shy acceptation like the original sin.

Woman's biology determines her characteristics and is a main part of her psychic (personality). Personality, which we can call mature or integrated, is dependent on co-operation of various spheres (bodily, philosophical, and spiritual). Changeability and cyclicality of woman's physiology determines her specificity.

"Maternal masterpiece of woman's body is a sign of untouched originality" [Echivard 1989: 46] is what Echivard says in his considerations about woman and emphasises that through the mystery of maternity woman's body shows that there is a sphere in which woman evades form man. Woman's body takes part in creative love. Biology of women works in such a way that, throughout the whole pregnancy, birth and breastfeeding woman's body experiences without a man. It is also difficult to share the biological and psychological experiences, which she lives through and which is her own time and experience. 
"Woman's body experiences its own "creation" as a biological sign of what in inseparable unity spiritual parson of woman also experiences. That is why child birth in its magical unusuality is the most perfect act, which unifies biological and spiritual aspects, nature with human being" [Echivard 1989: 46]

\subsection{Nature of Woman}

Nature is what exists on its own in contrast to the things we great and can influence.

Woman's nature can be understood in two ways; as a system of characteristic women qualities or as a system of factors influencing as a external environment (surrounding reality). Woman's qualities are what make woman's nature, differing from a man and those which are common for both sexes.

According to Estes [Estes 2001: 17] nature is a life supporting force without which women cannot exist. You can call it a powerful psychological element, natural psychic or instinctive nature. In various psychological theories, from different perspectives you could describe it as Id, ego, indirect nature.

In biology it would be described as typical nature, fundamental. Because it hidden, prophetic, among cactadoras [Cantadora - collecting old legends] is called a woman of great wisdom. According to Clarissa Pinkola Estes the idea of nature "wild woman is not because of religion, but practice, it psychology in the purest sense - it is the knowledge of soul. Without it women are not capable of to listen to the voice of soul or tune into their inner rhythms, without it the inner sight of women is as if being a dark hand". If woman loses this inner wisdom boredom and illusions paralise her. Estes writes that when woman loses contact with her instinctive psychic she becomes half ruined, because the primary nature is what brings integrity.

A big part in comprehending woman nature is cultural conditioning. Nature as a female spirit (dimension) of woman, as "genius of a woman" has to be developed, improves as everything that is good and is a task of each woman. The pope in the letter to women writes (1995)

These characteristics make women's nature:

- Ability to notice, which enriches correct understanding of the world

- Ability to bring truth into relationships and human relations

- Significant input in building the civilisation of love, forming relations, hierarchy and philosophy of life

In women's nature there is also a personal attitude deformed towards exaggeration (Stein says in this case it is too much personality) [Edyta Stein, Refleksje o kobiecie, /przekład J.I. Adamska/, 2005: 4], which inclines towards annexation of he whole human. It has to highlighted that th experiences of hundreds of years show, that a woman is capable of achievements in other areas, 
but the fact that women are able to act in so called male jobs is not equivalent with it being truly feminine and for women. The truly feminine are the ones connected with bringing up, care and these requiring services. It is highlighted that woman scientist is better fulfilled when what alive and personal is important.

Man concentrates his effort on things whereas woman is more personal, she get completely involved in everything she does. She cannot separate business, office matters from the vivid interest in her life but also of the people around her. The ability to concentrate on specific things let man to experience one-sided development, and woman is guided to aspire towards the entirety and uniformity and that again in double direction. Woman would like to grow in fullness and multilaterally, but also would like to help others in it.

Edyta Stein also explains, what she understands through the value of personal attitude and orientation for wholeness. Personal attitude is a valuable gift, because a person is above objects. Reality and truth about her are recognized by a person, this person admires the objects also in the sense of all material values are for the person. Behind everything that is of value in this world is the Creator as a prototype. In human as the highest creation of God is the most developed and in him God's gifts are the most visible. Such humanity and is development are for all human beings.

Stein claims that the longing for fullness of humanity is particularly strong in women, because she is involve in its special destiny - to be a companion and mother. "Being a mother - means to take care the real humanity, to protect it and help it develop" [Edyta Stein refleksje o kobiecie, /przekład J.I. Adamska/, 2005: 5]. Stein strongly emphasises that indispensable condition is the woman's following towards the complete humanity. The condition of being a mother can be met by a woman, who has the correct attitude. Stein puts a strong emphasis here on primary form of woman's specificity and defines it as degeneration and concealing the correct attitude.

Sometimes it is a tendency to threat herself with self importance to occupy herself and others (lust of love and admiration, inability to take criticism, which is consider attack on the person) [Edyta Stein refleksje o kobiecie, / przekład J.I. Adamska/, 2005: 5].

This requirement of importance, unrestricted recognition concerns everything that is characteristic for a person. Stein mentions that a woman can expect ideal husband imagines her children as the best, the most beautiful and intelligent. This blind love conceals objective judgement and means that woman is unable to realize her destiny.

In this exaggeration of self importance there is another thing that disturbing a tendency to be to interested in others, strong desire to be nosey about other people's life and to take their freedom away. "Exaggeration of own and other people's personality meets in woman's desire to surrender to lose themselves in 
another person" ) [Edyta Stein refleksje o kobiecie, /przekład J.I. Adamska/, 2005: 6]. Further Stein characterizes woman mentioning that in such a state of excess tendencies she is not able to be just [Justice can be understood here; Catechism of Catholic Church 1807 justice is a moral virtue, which is a constant and permanent will to devote to God and fellow human what is rightfully theirs.....] with humanity both their own and fellow human.

Two is requirement of entirety and compactness -desire to know everything and therefore to try everything and not to be deeply involved in anything. Superficiality resulting from it does not lead true humanity.

An ability to fundamentally capture one thing is important, that is why Stein writes the one who captures one thing fundamentally is closer to humanity that the one who does not feel confident where.

\section{The substance of harmony}

Using such concepts as balance or harmony we often narrow our considerations to chosen aspects not including other important factors, that is why it is worth to start a discussion about what we will consider environment and how we understand harmony, internal, external environment and nature.

Analysing integral vision of human's in John Paul teachings we can repeat after Pawlak [Pawlak 2004: 142], that the philosophy of human person by Wojtyła is one of the most important concepts of human being in previous anthropological thought.

With human concept the most important thing is starting point. Karol Wojtyła emphasises that knowledge about man we gather through experience. Gathered through experience commonly communicated knowledge not only outflows but also has an influence on experience and is in feed-back with it.

The starting point of Wojtyła's philosophical anthropology is person's experience. Primary human experience is his act, which is the key to the truth about man [Wojtyła 2000: 112]. Wojtyła claims that act is such a reality in which a whole person participates - its somatic dimension, psychic, spiritual and moral. It is through act that man most efficiently expresses.

\subsection{Harmony between internal and external environment}

Talking about harmony we think of both internal harmony, the one build inside man and external build with surroundings and transcendent reality.

Harmonious man, living full humanity lives in internal harmony and at the same time is in harmony with th surroundings. External environment are the biological, physiological and psychological processes. Psychophysical and spiritual unity decides about harmony. Internal balance is harmony which 
should be reached between elements at different levels. Each level has certain requirements and properties.

Harmony starts to gain legitimacy and depth in the context of disharmony through which a person lives through. Fighting woman cut off from her inner nature and apparent prime hides existential anxiety. Liberating herself from male domination she takes over male parts, disrupting the order and harmony in cooperation of nature and vocation.

Especially nowadays woman needs to specify herself and her identity. Woman is in alarming crisis of identity. Harmonious man means that he is in a relationship that he knows his value, respects others and himself. Divisions, separating what God has connected (especially the division between a woman and a man leads to a crisis in a relationship). In the description from Genesis crisis in the relationship started from the original sin.

From interpretation of the words from Genesis it results that a weakness of woman is her susceptibility for male imperiousness (towards your husband you will lead your desires). A task for each Christian is work on the weakness indicated by Jesus. The weakness of a woman is her too strong subjection to men, when the relationship is not within God's space or there is to strong competition in the fight against enslavement by a man (he will rule upon you). And even though their vocation to unifying love has not changed, these words indicate that true unconditional love will be realized and experienced in trials and suffering.

Eve is left with bidder strain, she is heart broken, she is not loved, respected, waited for by a man, she has lost his trust - he will rule upon you. "I woman, who is a more unified creature, when in the right harmony of a mediatory, fall to pieces in sin into fears, whims and desires. That is what surrenders her into 'ruling upon' by a man., Adam however is hurt he toils, because he does not love enough, because he is a prisoner of one activity - work,... he becomes a victim of spiritual ponderosity.

Women's liberation from male domination was followed by losing all the care. Woman experiences a hard trial of loneliness, in which he has to face it by herself. A dissonance between spiritual immaturity and civilisation progress shows, its characteristic is more sensitive and valuable new generation. Harmony whose guardian can and should be a woman will only have a chance to exist when woman is capable to do it both physically and spiritually. Woman aware of her role know she can play a significant role in various aspect of life. Woman's vocation, woman's liberation is there to support humanity not to oppress a man. 


\subsection{Relationship between three levels - psychic and functional dependence}

Balance between interior and nature is a result of the presence of three levels. Cencini presents unity somatic - relationship - rational, which in each act shows its complex substance as well as integrated image of life in psychological and Christian dimension.

According to Cencini a human can live at three different levels:

- Psycho physiological, which includes psychic factors in correlation with physical states of good and bad disposition dependent on satisfaction or lack of basic physiological needs of human body (hunger, thirst, sleep, happiness from health, being alive). The state of satisfaction or lack of basic physiological needs is felt at senses level. An item which relives the tension and satisfies the thirst comes from the outside of the individual, particular and specified. At the moment of satisfaction the item becomes as if the possession of the subject. Seeing reality at this level is fragmentised and not full, it restricts to seeing ones physiological need so it is subjective. Purposefulness which is connected with the needs is the aspiration to life support and ofselfpreservation.

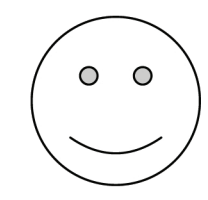

SUBJECT

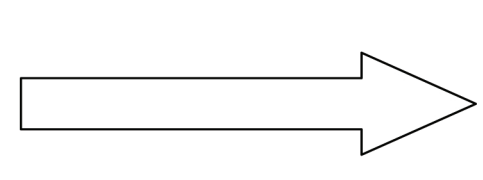

OUTGOING ACTION

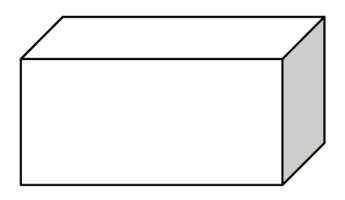

OBJECT

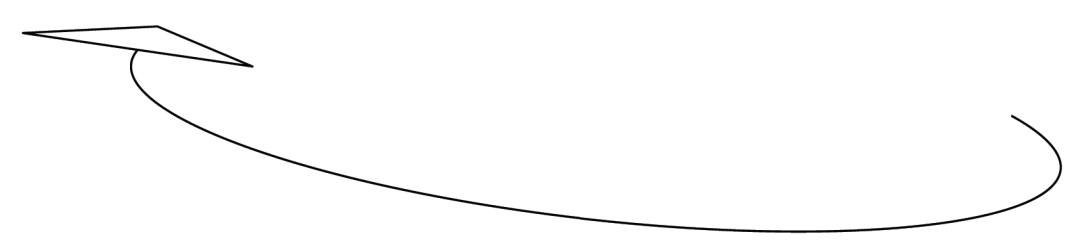

INCOMING ACTION

- Psycho - social, which includes psychic activates connected with social relations. A motivation for starting social relations is not satisfying basic activates but realization of one's own limitations and own insufficiency. The subject o satisfaction is something not specific not like at the first level, but another person. A person is from outside, but cannot become something appropriated, internal like it was in case of an object, because a person is not an object. Reality which we see at this level is mainly the reality of 
people. Human at this reality looks for gratuity in relationships. The observed reality is the reality of people, but observed not only with their inner value but also in relation to their positive relationship. Such experience allows to get into relationships with people, but also to notice common good. In such relationships we can see a need to expand or to self-realisation through another person. Mentioning the above Nuttin [Cencini 2002: 290-295] notices that at the psychic level human is a creation with its own right, significantly dependant on another person.

- Rational -spiritual involves psychic activities connected with the need to know the truth and ability to comprehend the nature of objects, throughout separating it from the sensual data. The Rational - spiritual level differs od from other creatures because of the ability comprehend things. The power of comprehension allows human beings to form rules, abstract concepts and laws that rule the sensual data and explain them.

These three levels are interconnected with each other bur clearly recognizable in particular actions. If we talk about the difference between man and woman is can be noticed in particular actions. Each level will characterize certain weaknesses, or even will indicate the sex.

Wojtyła in his teachings about man introducer a concept "adequate anthropology" [Adequate anthropology remains on "human experiencing of man" as opposed to naturalistic reductionalism]. Based on this anthropology we can seek woman's harmony and her internal and external conditioning.

According to Wojtyła the experience of human actions discloses in two ways:

- Action ( act indicating activity)

- Happening (something happens in a human)

In these two forms of human dynamism we can notice human activity (action) and passiveness. Wojtyła distinguishes as a consequence of this division acts as a conscious human activity and "happenings" as a statement that happens in a human. "Happenings" as a human act can be compared with nature, which according to Zięba [Zięba 2008: 225-227] can mean an important characteristic or a property of something (a power that is present at the base of events in the world). Human act is connected with the choice of man, with his freedom and as a consequence with responsibility. The source for happenings is creative human nature.

Harmony between needs, values and norms lead attention on very significant dimension of human which is its ethical dimension. Grabowski [Grabowski 2004: 28] draws attention to the possibility of new view on the biblical symbols of the tree of Eden and indicated another outlining anthropology, which does not put the human intellect in the first place, but the ability to enter relationships with values, that is on ethical aspect of human.

Harmony in the area of needs and values is a very important aspect. Human balances in the sphere of motivations between needs, which activate him from 
inside and external factors such as norms. Human also possesses feeling of duty of himself and in this aspect there is a difference between men and women. Social norms set the aim and way of life.

ACTIVITY DIAGRAM OF HUMAN EXPERIENCE BY K.WOJTYLA (worked out by I.Grochowska)

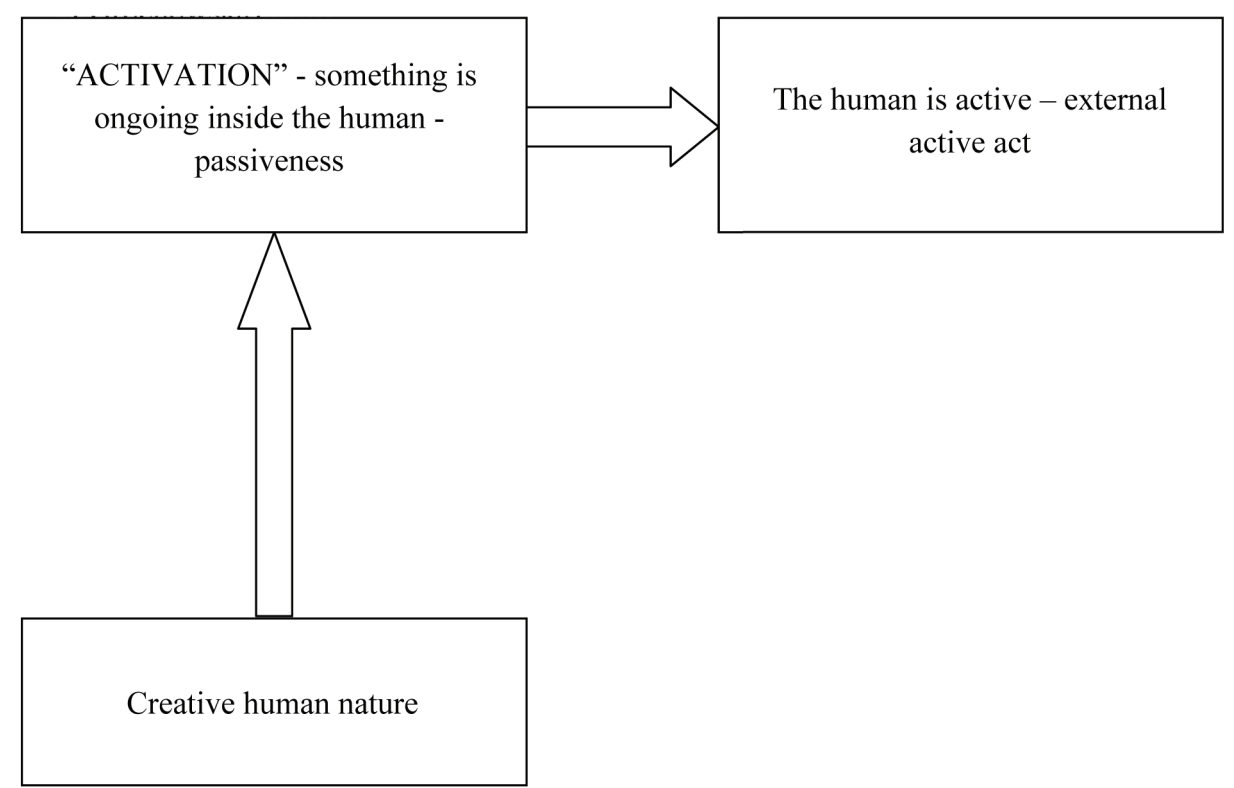

Ceccini quotes in his considerations the rule of wholeness, which ensures external balance. He specifies in it dependencies:

- Psychic dependency - it is an act off free will dependant on basic needs (for example rest), from good or bad internal disposition, that is a result of positive or negative social relation. The physiological condition and social openness depend on (in other and more subtle and complex way) from the way of experiencing the rational - spiritual level (for example from inner peace).

- Functional dependency - in order for spiritual activity to be really undertaken it needs not only other levels but also particular and well functioning nervous centres an physiological structures within them, which allow the intellect to think, memory for memory, the word to explain thought, give functions to society (natural law). Biological somatic organisation (homeostasis) are under static and dynamic criteria of the whole human body and the set balance between good imposition of particular limbs and overall imposition of the body. Physiological level is arranged through cells, tissues, chemical reactions whilst internal organs perceptionally receive, notice stimuli such as sleepiness, hunger. 


\section{Conclusion}

Dominant culture is 'cynical' in relation to women. On one hand it declares care about women and her femininity and on the other fights with her proposing and enabling solutions which cause a dilemma, internal conflict and as a consequence disintegration of woman's personality.

Mary E. Homes and Allen D. Krammer's study [Gomes, Kanner 1995: 111122] show how feminist philosophy relates to environment's health and shows that Earths destruction and domestication of women are closely related.

The influence of culture and proposed life style has a significant influence on young women. Proposals that guarantee easier way to deal with problems win even with accepted outlook on life and resulting from it responsibilities. Difficult to accept characteristics of women that are the result of hormone physiology are most likely solved by easier methods such ad contraceptives or in vitro.

In recent years a new integrated method of certain about hormonal development of women and of life with full femininity has occurred. The knowledge of this method allows to connect the knowledge of proper functioning of female organism taking into account all spheres (psychic, spiritual, biological and social).

Naprotechnology [Hilgers 2004: 19] (NaProTechnologia) is derived from "natural procreative technology" and it can be said that it looks after natural support of fertility., solving woman's problems of gynaecological - reproductive nature. It can be characterized with a certain way of thinking from which action results. Naprotechnology co-operates with natural cycle of women and allows to accurately specify reasons for infertility, to diagnose them and treat. I have to mention here that Naprotechnology is not only supporting the diagnosis of infertility but also help in treatment of other conditions of reproductive system.

\section{References}

1. Echivard N., Kobieto, kim jesteś, w Drodze, Poznań 1989.

2. Estes P., Biegnąca Z wilkami, Zysk i S-ka, Poznań 2001.

3. Edyty Stein refleksje o kobiecie, /przekład J. I. Adamska/, Borne Sulinowo 2005.

4. Pawlak Z., Punkt wyjścia antropologii filozoficznej w: O antropologii Jana Pawła II, /red./ M. Grabowski, Wydawnictwo Uniwersytetu Mikołaja Kopernika, Toruń 2004.

5. Gomes M., Kanner A., The Rape of the Well-Maidens: Feminist Psychology and the enviromental Crisis w; Ecopsychology, /editors/ T. Roszak, M. Gomes, A. Kanner, Sierra Club Books, San Francisco 1995.

6. Wojтyєa K., Osoba i czyn oraz inne studia antropologiczne, Towarzystwo Naukowe KUL, Lublin 2000.

7. Mężczyzną i niewiastą stworzył ich, o Jana Pawła II teologii ciała /red./ T. Styczeń, KUL, Lublin 1998.

8. ZIĘBA S., Perspektywy ekologii człowieka, Wydawnictwo KUL, Lublin 2008.

9. Hilgers T. W., The medical and surgical practice of NaProTECHNOLOGY, Pope Paul Institute Press, Omaha, Nebraska 2004. 
Irena Grochowska

10. Cencini A,. Psychologia i formacja, WAM, Kraków, na podstawie J.Nuttin, Psicanalisi e personalita, Padine Alba 2002.

11.JAWORSKi R., Harmonia i konflikty, Wydawnictwo Kardynała Stefana Wyszyńskiego, Warszawa 2006.

12.WYSZYŃsKi S., Godnośc kobiety, Instytut Wydawniczy PAX, Warszawa 2001.

\section{STRESZCZENIE}

Szeroko rozumiana i uprawiana ekologia człowieka dotyczy całokształtu relacji człowiek - środowisko. Należałoby się zastanowić, czy można mówić osobno o ekologii kobiety i mężczyzny.

W antropologii chrześcijańskiej kobieta i mężczyzna funkcjonują w jednym człowieczeństwie co do godności, ale jako kobieta i mężczyzna co do sposobu ukonstytuowania. Na ludzką pełnię składają się dwa odmienne czynniki spełnione w płciowości. Płeć różnicuje człowieka w wymiarze biologicznym, psychicznym, społecznym, w konsekwencji i kulturowym. Dlatego niech będzie usprawiedliwionym rozważanie osobowości i natury kobiet $\mathrm{w}$ ich swoistym środowisku, jako ekologii kobiety. Pozwoliłam sobie na użycie terminu ekologia kobiety, gdyż odnoszę wrażenie, że ekologia (gr. oikos - dom) jako nauka o „domu” o najbliższym środowisku trafnie oddaje sens środowiska, aury jaką tworzy kobieta wokół swojej osoby.

Dominująca kultura jest "cyniczna” w odniesieniu do kobiet. Z jednej strony deklaruje dbałość o kobietę i jej kobiecość, z drugiej strony walczy z nią proponując i umożliwiając rozwiązania, które doprowadzają do rozdarcia, do konfliktu wewnętrznego, w konsekwencji do dezintegracji osobowości kobiety.

Wyzwolenie się kobiety spod męskiej dominacji pociągnęło za sobą pozbycie się wszelkiej opieki. Kobieta doświadcza więc ciężkiej próby samotności, w której musi stawić czoła zupełnie sama. Taka sytuacja jest zachwianą równowagą, która w łańcuchowej reakcji dotyka innych a szczególnie dzieci. Zarysowuje się rozdźwięk między niedojrzałością duchową a postępem cywilizacyjnym, charakteryzujący się coraz większą wrażliwością i kruchością nowego pokolenia. Harmonia, której strażniczką może i powinna być kobieta ma szansę zaistnieć wtedy, kiedy kobieta jest do tego zdolna fizycznie i duchowo. Świadoma swej roli kobieta wie, że może odegrać doniosłą rolę w różnych dziedzinach życia. Kobiece powołanie, kobiece wyzwolenie ma służyć podbudowaniu ludzkości, a nie zgnębieniu mężczyzny.

Dla uzyskania obrazu harmonii należy ukazać przynajmniej najbardziej istotne elementy kształtujące zarówno harmonię wewnętrzną w człowieku, jak również jego harmonijne relacje $\mathrm{z}$ otoczeniem. W podjętej dyskusji chciałabym się zająć ekologią kobiety czyli tym, co jest w przypadku jej środowiska charakterystyczne i specyficzne dla niej i co ją odróżnia od mężczyzny i jego wpływu na otoczenie.

Ważnym zagadnieniem harmonii będą jej elementy, które stanowią o jej pełni. Harmonia między potrzebami, wartościami i normami będzie omówiona w szerszym aspekcie jako tło do rozważań o akceptowaniu kobiecości jako warunku koniecznego do utrzymania równowagi we wszystkich sferach ludzkiego życia. 